\title{
The Life of the Human Kidney Before Birth: Its Secrets Unfold
}

\author{
ADRIAN S. WOOLF \\ Nephro-Urology Unit, Institute of Child Health, University College London, London WC1N 1EH, U.K.
}

Human kidney and lower urinary tract malformations are a major cause of chronic renal failure in young children. Evidence is emerging that at least some of these disorders have a defined genetic basis. This is a rapidly evolving field, with new human mutations and informative animal models described almost monthly. In this review, we provide a background on important animal studies and then address human kidney development, highlighting recent studies where specific genes have been implicated in the pathogenesis of disease.

A potent blend of classical embryology and molecular genetics is illuminating mechanisms of kidney and lower urinary tract development. Most studies use mice in which growth of the adult kidney precursor, the metanephros, is manipulated by upregulation or down-regulation of molecules expressed during renal development, or nephrogenesis. A recent review (1) documented about 20 varieties of mice with mutations of diverse transcription factors, growth/survival factors, and matrix molecules, all with urinary tract malformations. Impressively, hierarchical networks of "master genes" affecting nephron development are being mapped (1). These experiments also demonstrate that disease phenotypes may depend on yet-to-be-discovered, straindependent, modifying genes, as well as mutations of single, key nephrogenesis genes. Furthermore, mutations of homologous genes may summate to disrupt of development (2). The differentiation of more primitive pronephric kidneys of fish (3) and toads (4) is also being explored, revealing remarkable conservation of nephrogenic genes between diverse species.

While it is tempting to speculate that "kidney-specific" master genes exist, so far all mouse genes implicated in urinary tract development are also expressed in diverse other organs: consequently, mutants often have multiorgan malformation syndromes e.g. the paired-box 2 (PAX2) transcription factor controls renal and ocular development (5). Other animal experiments indicate that physical obstruction of the fetal urinary tract, teratogenic drugs, exposure to excess glucose from maternal diabetes, as well as deficiencies in maternal protein and vitamin intake, can also perturb normal kidney development $(6,7)$.

Received June 7, 2000; accepted July 27, 2000.

Correspondence and reprint requests: Professor Adrian S Woolf, Head of the NephroUrology Unit, Institute of Child Health, University College London, 30 Guilford Street, London WC1N 1EH, U.K.
Apart from furthering our basic knowledge about organogenesis, it is timely to ask whether animal studies help us understand how human kidneys develop, not least because most children with chronic renal failure are born with abnormal urinary tracts $(8)$.

The human metanephros appears at $5 \mathrm{wk}$ after fertilization: it comprises the ureteric bud, an epithelial branch of the mesonephric duct, and renal mesenchyme, a caudal section of intermediate mesoderm. The bud tip branches to generate collecting ducts, while its stalk forms renal pelvis and ureter urothelium. The insertion of the bud into the mesonephric duct becomes incorporated into the cloaca, forming the urinary bladder trigone. Meanwhile, renal mesenchyme transforms into epithelial nephrons, with new glomeruli generated between 8 and 34 wk of gestation (9).

When these complex morphogenetic events go wrong, diverse kidney human malformations occur including agenesis (absent kidney), dysplasia (incomplete differentiation, often with cysts), and hypoplasia (too few nephrons) (10). Moreover, since physical engagement and subsequent interaction between ureteric bud and mesenchyme are essential for differentiation of each partner (1), it is not surprising that kidney malformations are often accompanied by lower urinary tract anomalies including agenesis, duplication, or hydroureter caused by impaired urine flow or vesicoureteric reflux $(10,11)$.

Alterations of maternal diet perturb nephrogenesis in rats, but there is no hard evidence that this occurs in humans. Although human renal malformations have been documented after exposure to angiotensin converting enzyme inhibitors, excessive glucose and ethanol (10), a history of teratogen exposure is rarely elicited.

More impressive is the common association of human kidney malformations with lower urinary tract obstruction, e.g. atretic ureters attached to multicystic dysplastic kidneys, ureteroceles, and urethral valves. In these cases, however, the cause of the obstruction itself remains unexplained, and it could be argued that both the malformed kidney and the obstructive lesion result from a more fundamental problem such as the altered activity of a gene expressed in both upper and lower urinary tract: indeed, genes with such widespread expression patterns exist in mice $(12,13)$ and humans (14). Finally, in many individuals with dysplastic or hypoplastic kidneys, the urinary tract is patent and hence physical obstruc- 
tion cannot be implicated in pathogenesis of the renal malformation.

Data are accumulating that some human urinary tract malformations have genetic bases.

One line of evidence is provided by the observation that such malformations may occur in multiple members of a family, more than would be expected by chance (10). A common example, affecting $1 \%$ to $2 \%$ of very young children, is vesicoureteric reflux, the retrograde passage of urine into the ureter and, occasionally, the renal parenchyma: in some families this is inherited in a dominant manner with incomplete penetrance (10). Based on a genome-wide analysis in seven Caucasian kindreds with three to seven affected members, Feather et al. (15) suggested that the disorder was genetically heterogeneous with some families mapping to chromosome 1p13: the causative gene, however, remains to be defined.

In other human urinary tract malformations, although simple inheritance patterns are not apparent, modifying genetic influences could operate (10). An example is provided by the association of a polymorphism, or common genetic variation, of the angiotensin II type 2 receptor (AT2) gene with a spectrum of disorders including pelviureteric junction obstruction and megaureter $(13,16)$. The genetic variant most likely affects splicing and mRNA transcript levels of this growth factor receptor implicated in cell survival in developing kidney and lower urinary tract (13). Furthermore, male mice with null mutation of AT2, located on the X chromosome, display a low penetrance of diverse urinary tract malformations (13).

Other clues come from the discovery that specific malformation syndromes affecting the kidney are caused by mutations: in other such multiorgan syndromes, disease loci have been established while genes have yet to be defined. A selection of these disorders are shown in Table 1. Although such syndromes are individually rare, there are a considerable number of them $(17,18)$, collectively accounting for significant morbidity.

An early discovery was that deletion of the WT1 gene accounted for genitourinary malformations in the WAGR syndrome, a condition associated with Wilms' tumor and aniridia, the latter caused by deletion of the nearby gene PAX6 (19). WT1 is a transcription factor active in metanephric mesenchyme, and null mutant mice have renal agenesis (1). In the case of PAX2 mutations, mouse and human disease show striking parallels with urinary tract and eye malformations (5): this gene is expressed in mesonephric duct, fetal collecting ducts, and nascent nephrons but is down-regulated at the end of organogenesis $(10,14)$. I will highlight two more such syndromes in which animal studies act as paradigms for human disease.

The Simpson-Golabi-Behmel syndrome is a human disease in which overgrowth of diverse organs causes malformation (e.g. renal cystic dysplasia) and tumor formation (20). It forms part of a spectrum of overgrowth disorders including genetically distinct Beckwith-Weideman and Perlman syndromes (20). Mutations of the glypican-3 (GPC3) gene have been identified in the Simpson-Golabi-Behmel syndrome (21). This codes for a heparan sulfate proteoglycan expressed during
Table 1. Genetics of human urinary tract malformations

Apert syndrome (FGFR2* mutation - growth factor receptor): hydronephrosis and duplicated renal pelvis

Bardet Biedl syndrome (loci on 11q13, 16q22, 3p13, 15q21 and 2q31): renal dysplasia and calyceal malformations

Beckwith-Wiedemann syndrome (in a minority of patients, p57KIP2* mutation - cell cycle gene): renal overgrowth, cysts and dysplasia

Branchio-oto-renal syndrome (EYA1* mutation - transcription factor): renal agenesis and dysplasia

Campomelic dysplasia (SOX9 mutation - transcription factor): diverse renal malformations

Carnitine palmitoyltransferase II deficiency (gene for this enzyme is mutated): renal dysplasia

Congenital anomalies of the kidney and urinary tract (CAKUT) syndrome (AT2* polymorphism - growth factor receptor): diverse renal and lower urinary tract malformations

Diabetes and renal malformation syndrome (HNF1 $\beta$ mutation transcription factor): renal dysplasia, hypoplasia and glomerular cysts

Di George syndrome (locus on 22q11): renal agenesis, dysplasia and vesicoureteric reflux

Glutaric aciduria type II (glutaryl-CoA dehydrogenase mutation): cystic and dysplastic disease

Fanconi anaemia (FAA family mutation - DNA repair molecule): renal agenesis, ectopic/horseshoe kidney

Kallmann's syndrome (KAL1 mutation - cell signaling molecule): renal agenesis

Meckel syndrome (locus on 17q21-q24): renal cystic dysplasia

Nail-patella syndrome (LMX1B* mutation - transcription factor): glomerulus dysgenesis

Renal-coloboma syndrome (PAX2* mutation - transcription factor): renal hypoplasia and vesicoureteric reflux

Simpson-Golabi-Behmel syndrome (GPC3* mutation - proteoglycan): renal overgrowth, cysts and dysplasia

Smith-Lemli-Opitz syndrome ( $\delta(7)$-dehydrocholesterol reductase mutation cholesterol biosynthesis): renal cysts and dysplasia

WAGR, Denys Drash and Frasier syndromes (WT1* mutation transcription/splicing factor): lower urinary tract malformations and glomerular sclerosis

Zellweger syndrome (peroxisomal protein mutations): cystic dysplastic kidneys

See text and references 17 and 18 for details; * mutations of these genes are also implicated in mouse malformations.

human organogenesis (22). The molecule binds to cell surfaces and, in vitro, is implicated in cell survival (23). Null mutant mice also develop an overgrowth syndrome with cystic ureteric bud/collecting duct hyperproliferation (24). Superficially similar aberrations of cell turnover have been reported in sporadic cases of human renal cystic dysplasia $(14,25)$, and although these individuals lack other features of the syndrome, it would be interesting to search for GPC3 mutations in these patients.

The hepatocyte nuclear factor $1 \beta(\mathrm{HNF} 1 \beta)$ gene is implicated in endoderm development (26), with human mutations associated with MODY (maturity onset diabetes mellitus of the young): these individuals have a failure of pancreatic insulin secretion $(27,28)$. The gene is also expressed in developing urinary tract (29) and mutations in the DNA binding and transactivating domains of this transcription factor have been reported in patients with kidney malformations including dysplasia (27), hypoplasia (28), and glomerulocystic disease (30), a form of polycystic kidney in which glomerular cysts predominate. Although embryonic mouse null mutants die before the urinary tract is formed, zebrafish experiments show that intro- 
duction of a human mutation perturbs kidney precursor development in a dominant-negative manner with formation of cyst-like structures (4).

Evidence is emerging that some human urinary tract malformations have a genetic basis and key "nephrogenesis genes" are conserved between human, murine, and other animal species. In the near future, it will be possible to envisage that some of these discoveries may form the basis of genetic screening tests for urinary tract malformations: in the much longer term, a better understanding of disease mechanisms could lead to novel drug-based, cellular or genetic therapies to enhance the differentiation of nephrogenic precursor cells. The feasibility of such therapies has at least begun to be explored by the experimental use of metanephric precursor cells that can be genetically altered ex vivo and then transplanted into postnatal animals where they differentiate into functioning kidney tissue (31-32).

1. Kuure S, Vuolteenaho R, Vainio S 2000 Kidney morphogenesis: cellular and molecular regulation. Mech Dev 92:19-30

2. Kume T, Deng K, Hogan BLM 2000 Murine forkhead/winged helix genes Foxc1 (Mf1) and Foxc2 (Mfh1) are required for the early organogenesis of the kidney and urinary tract. Development 127:1387-1395

3. Drummond IA 2000 The zebrafish pronephros: a genetic system for studies of kidney development. Pediatr Nephrol 14:428-435

4. Wild W, von Strandmann EP, Nastos A, Senkel S, Lingott-Frieg A, Bulman M, Bingham C, Ellard S, Hattersley AT, Ryffel GU 2000 The mutated human gene encoding hepatocyte nuclear factor $1 \beta$ inhibits kidney formation in developing Xenopus embryos. Proc Natl Acad Sci USA 97:4695-4700

5. Favor J, Sandulache R, Neuhauser-Klaus A, Pretsch W, Chaterjee B, Senft E, Wurst W, Blanquet V, Grimes P, Sporle R, Schughart K 1996 The mouse Pax $2^{1 \mathrm{Neu}}$ mutation is identical to a human PAX2 mutation in a family with renal-coloboma syndrome and results in developmental defects of the brain, ear, eye and kidney. Proc Natl Acad Sci USA 93:13870-13875

6. Attar R, Quinn F, Winyard PJD, Mouriquand PDE, Foxall P, Hanson MA, Woolf AS 1998 Short-term urinary flow impairment deregulates PAX2 and PCNA expression and cell survival in fetal sheep kidneys. Am J Pathol 152:1225-1235

7. Lelievre-Pegorier M, Merlet-Benichou C 2000 The number of nephrons in the mammalian kidney: environmental influences play a role. Exp Nephrol 8:63-65

8. Warady BA, Hebert D, Sullivan EK, Alecander SR, Tejani A 1997 Renal transplantation, chronic dialysis, and chronic renal insufficiency in children and adolescents. Pediatr Nephrol 11:49-64

9. Risdon RA, Woolf AS 1998 Development of the kidney. In: Jennette JC, Olson JL, Schwartz MM, Silva FG (eds) Heptinstall's Pathology of the Kidney, 5th Ed. Lippincott-Raven, Philadelphia-New York, pp 67-84

10. Woolf AS 2000 A molecular and genetic view of human kidney and urinary tract malformations. Kidney Int 58:500-512

11. Schwartz RD, Stephens FD, Cussen LJ 1981 The pathogenesis of renal dysplasia. II. The significance of lateral and medial ectopy of the ureteric orifice. Invest Urol 19:97-100

12. Miyazaki Y, Oshima K, Fogo A, Hogan BLM, Ichikawa I 2000 Bone morphogenetic protein 4 regulates the budding site and elongation of the mouse ureter. J Clin Invest 105:863-873

13. Nishimura H, Yerkes E, Hohenfellner K, Miyazaki Y, Ma J, Huntley TE, Yoshida H, Ichiki T, Threadgill D, Phillips JA 3rd, Hogan BM, Fogo A, Brock JW 3rd, Inagam
T, Ichikawa I 1999 Role of the angiotensin type 2 receptor gene in congenital anomalies of the kidney and urinary tract, CAKUT, of mice and men. Mol Cell $3: 1-10$

14. Winyard PJD, Risdon RA, Sams VR, Dressler GR, Woolf AS 1996 The PAX2 transcription factor is expressed in cystic and hyperproliferative dysplastic epithelia in human kidney malformations. J Clin Invest 98:451-459

15. Feather SA, Malcolm S, Woolf AS, Wright V, Blaydon D, Reid CJD, Flinter FA, Proesmans W, Devriendt K, Carter J, Warwicker P, Goodship THJ, Goodship JA 2000 Primary, non-syndromic vesicoureteric reflux and its nephropathy is genetically heterogeneous with a locus on chromosome 1 Am J Hum Genet 66:14201425

16. Hohenfellner K, Huntley TE, Schloemer C, Brenner W, Yerkes E, Zepp F, Brock JW 3rd, Kon V 1999 Angiotensin type 2 receptor is important in the normal development of the ureter. Pediatr Nephrol 13:187-191

17. McKusick VA Online Mendelian Inheritance in Man. National Center for Biotechnology Information http://www4.ncbi.nlm.nih.gov/Omim/

18. Woolf AS, Winyard PJD 1998 Advances in the cell biology and genetics of human kidney malformations. J Am Soc Nephrol 9:1114-1125

19. Pritchard-Jones K 1999 The Wilms' tumour gene, WT1, in normal and abnormal nephrogenesis. Pediatr Nephrol 13:620-625

20. Li M, Squire JA, Weksberg R 1998 Overgrowth syndromes and genomic imprinting: from mouse to man. Clin Genet 53:165-170

21. Veugelers M, Cat BD, Muyldermans SY, Reekmans G, Delande N, Frints S, Legius E, Fryns JP, Schrander-Stumpel C, Weidle B, Magdalena N, David G 2000 Mutational analysis of the GPC3/GPC4 glypican gene cluster on Xq26 in patients with Simpson-Golabi-Behmel syndrome: identification of loss-of-function mutations in the GPC3 gene. Hum Mol Genet 22:1321-1328

22. Pellegrini M, Pilia G, Pantano S, Lucchini F, Uda M, Fumi M, Cao A, Schlessinger D, Forabosco A 1998 Gpc3 expression correlates with the phenotype of the SimpsonGolabi-Behmel syndrome. Dev Dyn 213:431-439

23. Gonzalez AD, Kaya M, Shi W, Song H, Testa JR, Penn LZ, Filmus J 1998 OCI-5/GPC3, a glycipan encoded by a gene that is mutated in the Simpson-GolabiBehmel overgrowth syndrome, induces apoptosis in a cell line-specific manner. J Cell Biol 141:1407-1414

24. Cano-Gauci DF, Song HH, Yang H, McKerlie C, Choo B, Shi W, Pullano R, Piscione TD, Grisaru S, Soon S, Sedlackova L, Tanswell AK, Mak TW, Yeger H, Lockwood GA, Rosenblum ND, Filmus J 1999 Glycipan-3-deficient mice exhibit development overgrowth and some of the abnormalities typical of Simpson-Golabi-Behmel syndrome. J Cell Biol 146:255-264

25. Winyard PJD, Nauta J, Lirenman DS, Hardman P, Sams VR, Risdon AR, Woolf AS 1996 Deregulation of cell survival in cystic and dysplastic renal development. Kidney Int 49:135-146

26. Barbacci E, Reber M, Ott M, Breillat C, Huetz F, Cereghini S 1999 Variant hepatocyte nuclear factor 1 is required for visceral endoderm specification. Development 126:4795-4805

27. Bingham C, Ellard S, Allen L, Bulman M, Shepherd M, Frayling T, Berry PJ, Clark PM, Lindner T, Bell GI, Ryffel GU, Nicholls AJ, Hattersley AT 2000 Abnormal nephron development associated with a frameshift mutation in the transcription factor hepatocyte nuclear factor-1 $\beta$. Kidney Int 57:898-907

28. Lindner TH, Njolstad PR, Horikawa Y, Bostad L, Bell GI, Sovik O 1999 A nove syndrome of diabetes mellitus, renal dysfunction and genital malformation associated with a partial deletion of the pseudo-POU domain of hepatocyte nuclear factor- $1 \beta$. Hum Mol Genet 8:2001-2008

29. Coffinier C, Barra J, Babinet C, Yaniv M 1999 Expression of vHNF/HNF1 $\beta$ homeoprotein gene during mouse organogenesis Mech Dev 89:211-213

30. Bingham C, Bulman MP, Ellard S, Allen LIS, Lipkin GW, vant Hoff WG, Woolf AS, Rizzoni G, Novelli G, Nicholls A, Hattersley AT (2001) Mutations of the hepatocyte nuclear factor-1 $\beta$ gene are associated with familial hypoplastic glomerolocystic kidney disease. AM J Hum Genet (in press)

31. Woolf AS, Bosch RJ, Fine LG 1993 Gene transfer into the mammalian kidney: microtransplantation of retrovirus-transduced metanephric tissue. Exp Nephrol $1: 41-48$

32. Rogers SA, Lowell JA, Hammerman NA, Hammerman MR 1998 Transplantation of developing metanephroi onto adult rats. Kidney Int 54:27-37 